\title{
Saffron (Crocus sativus L): Kandungan dan Aktivitas Farmakologinya
}

\author{
Maryam Nur Afifah",1, Aliya Nur Hasanah²
}

${ }_{1}^{1}$ Program Studi Profesi Apoteker, Fakultas Farmasi, Universitas Padjadjaran, Jatinangor 45363

2Departemen Analisis Farmasi dan Kimia Medisinal, Fakultas Farmasi, Universitas Padjadjaran, Jatinangor 45363

*E-mail: maryam15002@mail.unpad.ac.id

(Submit 13/2/2020, Revisi 15/2/2020, Diterima 25/2/2020)

\begin{abstract}
Abstrak
Crocus sativus L. atau yang lebih dikenal Saffron saat ini sedang banyak diperbincangkan oleh masyarakat luas terutama di Indonesia. Saffron dengan aroma, warna dan rasa yang unik telah digunakan sebagai bahan makanan dan juga pengobatan tradisional di berbagai belahan dunia. Artikel ini bertujuan untuk memberikan review mengenai studi yang dilakukan pada kandungan dan efek farmakologis Crocus sativus L. Metode yang digunakan dalam review ini menggunakan sumber data jurnal Internasional dimana pencarian sumber data jurnal Internasional menggunakan instrumen pencari online yang bersumber dari Google, Googlescholar, Science direct, Pubmed dan lainnya. Kandungan utama yang terkandung dalam saffron yaitu crocin, crocetin, picrocrocin dan safranal. Aktivitas farmakologi yang dimiliki oleh saffron antara lain sebagai antikanker, antidepresi, antihipertensi, anticemas dan insomnia serta sebagai pengobatan Pre Menstrual Syndrome (PMS). Berdasarkan aktivitas farmakologi yang dimiliki ini maka Crocus sativus $L$ memiliki potensi untuk pengobatan beberapa penyakit. Namun, perlu adanya uji klinik yang lebih besar dilakukan untuk memastikan efek farmakologi yang dimiliki oleh saffron.
\end{abstract}

Kata Kunci: Crocus sativus, Saffron, aktivitas farmakologi

\section{Outline}

- Pendahuluan

- Hasil dan Pembahasan

- Kandungan utama

- Aktivitas Farmakologi

- Kesimpulan

- Daftar Pustaka

\section{Pendahuluan}

Crocus sativus L. saat ini sedang banyak diperbincangkan oleh masyarakat luas. Crocus sativus $L$. atau yang lebih dikenal dengan saffron dengan aroma, warna dan rasa yang unik dianggap sebagai pengantar baru untuk masakan dan obat-obatan pada abad ke $21^{1}$. Faktanya, Saffron (Crocus sativus Linn.) telah digunakan sebagai bahan makanan di berbagai belahan dunia sejak zaman kuno. 
Saffron juga digunakan dalam pengobatan tradisional dalam perawatan berbagai jenis penyakit. Saffron telah tertulis dalam resep tradisional termasuk obat-obatan Cina ,Ayurveda dan Yunani. Di Ayurveda, saffron digunakan untuk mengobati penyakit kronis seperti asma dan arthritis. Saffron juga digunakan untuk mengobati batuk dan demam².

Crocus sativus telah dilaporkan sebagai obat penenang, ekspektoran, anti asma, antikanker, dan antihiperlipidemia ${ }^{2}$. Penggunaan Saffron sebagai pengobatan untuk sekitar 90 penyakit telah terungkap dalam rentang waktu 4000 tahun. Saffron digunakan secara luas sebagai tanaman obat untuk memperbaiki kesehatan manusia terutama di Asia. Tanaman ini dikenal sebagai bumbu paling mahal di dunia dan telah dijuluki "Emas Merah" di Iran ${ }^{1,3}$. Diperkirakan Iran memproduksi sekitar $76 \%$ dari total produksi saffron di dunia setiap tahunnya ${ }^{4}$.

Di Indonesia pun saat ini sudah mulai dikonsumsi oleh banyak orang. Oleh karena itu, diharapkan dengan adanya review artikel ini semakin banyak yang mengetahui kandungan dan juga manfaat dari saffron. Review ini membahas mengenai kandungan yang terdapat dalam Saffron dan aktivitas farmakologi yang dimiliki oleh tanaman Saffron

\section{Metode}

Metode yang digunakan dalam review ini menggunakan sumber data jurnal Internasional dimana pencarian sumber data jurnal Internasional menggunakan instrumen pencari online yang bersumber dari Google, Googlescholar, Science direct, Pubmed dan lainnya. Kata kunci yang digunakan yaitu "Saffron", "Crocus sativus L", "pharmacology activity", "anticancer", "antihypertension", "treatment of anxiety" dalam pencarian data. Penelesuran lebih lanjut dapat melihat secara manual daftar pustaka yang relevan.

\section{Hasil dan Pembahasan}

\section{Kandungan saffron}

Analisis kimia menunjukkan adanya lebih dari 34 komponen volatile termasuk terpen, alkohol terpen dan esternya dalam saffron. Metodologi dan teknik yang digunakan untuk analisis metabolit saffron yaitu menggunakan teknik kromatografi dan spektroskopi seperti TLC, HPLC, GC-MS, LC-MS dan NMR ${ }^{5}$. Empat kandungan utama yang terdapat dalam Saffron yaitu crocin (monoglycosyl atau di-glycosyl polyene ester), crocetin (prekursor asam dikarboksilat karotenoid alami crocin), picrocrocin (prekursor glikosida monoterpen dari safranal dan produk degradasi zeaxanthin) dan safranal. Crocin sebagai pemberi warna pada saffron merupakan karotenoid yang larut dalam air karena memiliki kandungan glikosil yang tinggi. Picocrocin merupakan zat utama yang bertanggungjawab terhadap rasa saffron serta safranal merupakan minyak volatil yang bertanggungjawab terhadap aroma saffron ${ }^{6}$. Beberapa kandungan kimia pada saffron dapat dilihat pada Gambar 1. 


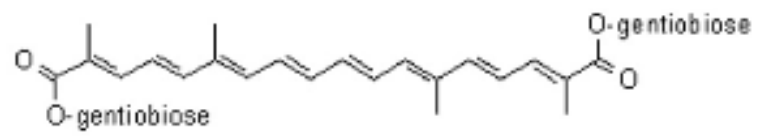

Crocin

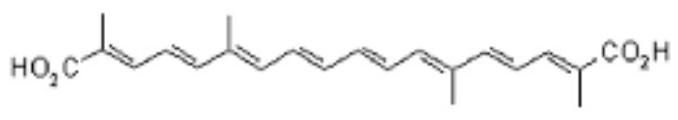

Crocetin
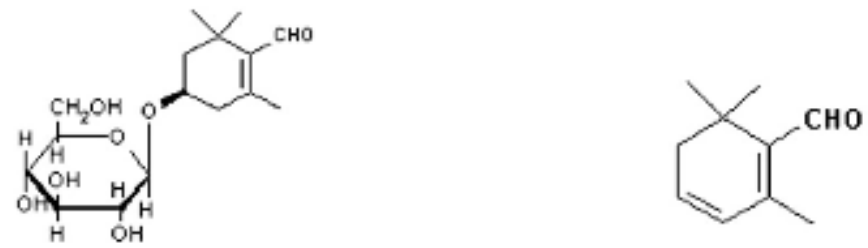

Picrocrocin

Safranal

Gambar 1. Kandungan kimia saffron ${ }^{1}$

\section{Aktivitas farmakologi}

\section{Antikanker}

Temuan ilmiah melalui model in vivo dan in vitro menunjukkan bahwa saffron dapat mempengaruhi karsinogenesis. Crocin dan crocetin yang terdapat dalam saffron memiliki aktivitas antikanker yang signifikan pada sel-sel payudara, paru, pankreas dan leukemia. Pengujian potensi saffron dalam menginduksi efek sitotoksik dan apoptosis pada sel kanker paru-paru A549 dilakukan. Sel A549 diinkubasi dengan berbagai konsentrasi ekstrak saffron, kemudian perubahan morfologi sel, viabilitas sel dan apoptosis ditentukan menggunakan invertmikroskop normal, nilai MTT, Annexin V dan iodide propidium. Berdasarkan hasil pengujian, ekstrak saffron mampu menurunkan proliferase sel A549, menginduksi perubahan morfologi serta meningkatkan persentase sel apoptosis ${ }^{7}$.

Eksperimen in vitro efek antikanker dari saffron telah difokuskan pada crocin sebagai senyawa antikanker yang penting dalam beberapa penghambatan pertumbuhan leukemia myelogenous kronis K562 dan sel leukemia promyelocytyc HL-60 oleh dimethylcrocetin, crocetin dan crocin ${ }^{8}$. Sitotoksitas dimethylcrocetin dan crocin pada sel leukemia L1210 dan leukemia P388 telah dilaporkan dengan konsentrasi 7-30 ppm untuk dimetilcrocin dan 11-39 ppm untuk crocin menghasilkan 50\% sitotoksisitas. Dimetilcrocetin dapat mengganggu interaksi DNA-protein yang penting untuk sintesis DNA seluler. Pemberian ekstrak saffron oral secara signifikan menghambat genotoksisitas yang diinduksi oleh cisplatin, mitomycin-C dan uretan dalam uji mikronukleus sumsum tulang tikus ${ }^{9}$.

Eksrak saffron secara in vitro juga telah diujikan dengan konsentrasi 200-2000 microgram $/ \mathrm{ml}$ dapat menurunkan viabilitas sel MCF-7 dengan tergantung pada dosiswaktu IC50 400 +/- 18,5 mikrog / ml setelah 48 jam. Saffron memberikan efek proapoptosis pada lini sel yang diturunkan dari kanker payudara dan dapat dianggap sebagai agen kemoterapi potensial pada kanker payudara ${ }^{10}$. 


\section{Antidepresan}

Saffron telah dikenal sebagai pengobatan depresi di pengobatan tradisional Persia. Sebuah penelitian dilakukan untuk membandingkan efektivitas saffron dengan imipramine menggunakan metode double blind randomized trial dilakukan di Rumah Sakit Jiwa Roozbeh antara Januari 2002 hingga Februari 2004. Pengujian dilakukan terhadap 30 pasien yang memenuhi kriteria Diagnostic and Statistic Manual of Mental Disorders edisi 4 untuk depresi mayor berdasarkan wawancara klinis secara terstruktur.

Pasien memiliki skor Hamilton Rating Scale for Depression setidaknya 18. Berdasarkan hasil pengujian, ekstrak ethanol saffron dengan dosis $30 \mathrm{mg} /$ hari memiliki efektivitas yang mirip dengan imipramine $100 \mathrm{mg} /$ hari dalam pengobatan depresi ringan hingga sedang. Efek samping mulut kering dan sedasi lebih banyak ditemukan pada penggunaan imipramine ${ }^{11}$. Aktivitas antidepresan dari ekstrak air dan ethanol saffron juga dilakukan terhadap hewan percobaan tikus dengan membandingkan dengan fluoxetin $(10 \mathrm{mg} / \mathrm{kg})$ dan imipramin $(15 \mathrm{mg} / \mathrm{kg})$. Berdasarkan pengujian yang dilakukan menggunakan metode FST, ekstrak ethanol saffron $(200-800 \mathrm{mg} / \mathrm{kg})$ dan ekstrak air $(160-320 \mathrm{mg} / \mathrm{kg})$ menunjukkan aktivitas antidepresan karena mengurangi waktu imobilitas seperti imipramin dan fluoxetin. Ekstrak air saffron pada metode OFT juga memperlihatkan mengurangi total lokomotor. Efek antidepresan ekstrak Crocus sativus karena kandungan safranal dan crocin di dalamnya. Crocin beraksi melalui inhibisi uptake dopamin dan norepinefrin dan safranal melalui serotonin ${ }^{12}$.

Sebuah meta analisis terkait efek suplemen saffron terhadap gejala depresi dilakukan. Berdasarkan kriteria yang telah ditentukan, lima uji acak terkendali (dua plasebo uji terkendali dan tiga antidepresan uji terkontrol) masuk ke dalam meta analisis. Hasil yang didapatkan yaitu saffron secara signifikan mengurangi gejala depresi dibandingkan dengan kontrol plasebo. Sebuah effect size antara suplemen saffron dengan kelompok antidepresan memperlihatkan bahwa keduanya memiliki efektivitas yang hampir sama dalam mengurangi gejala depresi. Skor Jadad yaitu lima menunjukkan pengujian berkualitas tinggi ${ }^{13}$.

\section{Anti hipertensi}

Pengujian efek antihipertensi yang dimiliki oleh C.sativus dilakukan terhadap 28 tikus Wistar jantan. Pengujian dilakukan dengan memberikan saffron $200 \mathrm{mg} / \mathrm{kg} / \mathrm{hari}$ per oral selama lima minggu pada tikus hipertensi. Hipertensi diinduksi oleh NG-nitro-L-arginine methyl ester (L-NAME; $40 \mathrm{mg} / \mathrm{kg} / \mathrm{hari}$ ) dan tekanan darah diukur setiap minggu. Berdasarkan penelitian yang dilakukan, penggunaan saffron secara rutin dapat mencegah terjadinya kenaikan tekanan darah pada tikus hipertensi dimulai dari minggu ketiga pengobatan ${ }^{14}$.

Pengujian dilakukan terhadap 80 subyek pasien DM tipe 2. Pengujian dilakukan menggunakan metode randomized-controlled trial dengan plasebo sebagai kontrolnya. Secara acak 40 pasien diberikan saffron dan 40 subyek lainnya diberikan plasebo selama 12 minggu. 
Alkali fosfatase (ALP), aspartat aminotransferase (AST), alanin aminotransferase (ALT), serum urea, kreatinin, 24 jam urin albumin, tekanan darah sistol, tekanan darah diastol, aktivitas fisik dan jumlah makanan yang masuk diukur sebelum dan sesudah percobaan. Berdasarkan pengujian yang dilakukan, $100 \mathrm{mg}$ per hari saffron memiliki hasil yang signifikan dalam menurunkan tekanan darah sistol $(P<0,005)$ bila dibandingkan dengan plasebo ${ }^{15}$. Efek penurunan tekanan darah oleh $C$. sativus pada tikus yang hipertensi dapat dimediasi melalui penghambatan kanal kalsium oleh crocetin ${ }^{16}$.

\section{Anticemas dan insomnia}

Sebuah studi menunjukkan aktivitas anti kecemasan oleh crocin dibandingkan dengan diazepam pada tikus menggunakan tes gerap terang. Tes ini menempatkan tikus dalam kotak dua kamar, satu terang dan satu gelap, dan mengukur waktu yang dihabiskan sebagai indikator kecemasan berdasarkan gagasan bahwa tikus akan menginginkan area gelap jika merasa dalam kecemasan tinggi.

Hasil penelitian menunjukkan bahwa pemberian crocin secara intraperitoneal dengan dosis tertinggi $(50 \mathrm{mg} / \mathrm{kg}$ ) mengurangi kecemasan mirip dengan diazepam seperti yang ditunjukkan oleh peningkatan kecenderungan untuk memasuki kamar gelap dan meningkatkan waktu keseluruhan secara keseluruhan di ruang cahaya ${ }^{17}$. Saffron sebelumnya telah disetujui sebagai terapi adjuvant yang efektif dalam depresi dan mungkin mengurangi gejala Generalized Anxiety Disorder (GAD). Dalam uji coba menggunakan double blind randomized controlled trial dengan subyek 40 pasien dengan gangguan ansietas ringan hingga sedang. 20 subyek menerima saffron $450 \mathrm{mg}$ dan 20 subyek menerima plasebo. Intervensi diberikan sebagai terapi tambahan untuk sertralin setiap hari selama enam minggu.

Berdasarkan hasil pengujian, saffron terbukti efektif dapat mengurangi Hamilton Anxiety Rating Scale (HAM-A) dibandingkan plasebo ${ }^{18}$.Komponen crocin dan safranal pada saffron terbukti efektif dapat digunakan sebagai pengobatan kecemasan melalui penekanan reuptake monoamin termasuk noreponefrin, serotonin dan dopamin. Efek lainnya yaitu penekanan $\mathrm{N}$-methyl-D-aspartate (NMDA), penekanan monoamin oksidase serta menghambat peningkatan kadar kortikosteron dalam plasma yang mempercepat kenaikan tingkat stress ${ }^{19,20}$.

\section{Pengobatan Pre Menstrual Syndrome (PMS)}

Sindrom pramenstruasi merupakan salah satu masalah kesehatan paling umum yang dilaporkan oleh wanita, yang mempengaruhi $20-40 \%$ wanita usia reproduktif. Hal ini ditandai dengan beberapa perubahan suasana hati dan perilaku21. Penelitian efek saffron dalam pengobatan PMS dilakukan terhadap 50 wanita usia 20-45 tahun dengan siklus menstruasi regular dan memiliki tanda PMS kurang dari 6 bulan sebelum pengujian. Sebanyak 25 subyek menerima kapsul saffron $30 \mathrm{mg} / \mathrm{hari}$ yaitu pada $15 \mathrm{mg}$ pada pagi dan malam hari dan sebanyak 25 kapsul plasebo diberikan dua kali sehari selama 2 siklus menstruasi. Berdasarkan pengujian yang dilakukan, saffron ditemukan efektif dalam meringankan gejala PMS. 
Perbedaan yang signifikan diamati dalam efikasi saffron pada siklus tiga dan empat menggunakan alat ukur Hamilton Depression Rating Scale dan Total Premenstrual Daily Symptoms ${ }^{22}$.

\section{Kesimpulan}

Berdasarkan pokok bahasan yang telah dibahas mengenai kandungan dan aktivitas farmakologi baik secara in vivo maupun in vitro, C. sativus atau Saffron dapat digunakan sebagai pengobatan beberapa penyakit dengan dosis yang sesuai. Namun, perlu adanya uji klinik yang lebih besar untuk memastikan efek farmakologi yang dimiliki oleh Crocus sativus L. atau saffron.

\section{Daftar Pustaka}

1. Melnyk JP, Wang S, Marcone MF. Chemical And Biological Properties of The World's Most Expensive Spice: Saffron. Food Research International. 2010; 43(8):19811989.

2. Rahmani AH, Khan AA, Aldebasi YH. Saffron (Crocus Sativus) And Its Active Ingredients: Role In The Prevention And Treatment Of Disease. Pharmacogn J. 2017;9(6):873-879.

3. Bolhassani A, Khavari A, Bathaie S. Saffron And Natural Carotenoids: Biochemical Activities And Anti-Tumor Effects. Biochimica et Biophysica Acta (BBA). 2014; 1845(1).

4. Milajerdi A, Djafarian K, Hosseini B. The Toxicity Of Saffron (Crocus Sativus L.) And Its Constituents Against Normal And Cancer Cells. Journal Of Nutrition \& Intermediary Metabolism. 2016;3:23-32.

5. Liakopoulou-Kyriakides M, Kyriakidis DA. Croscus Sativus-Biological Active Constitutents. Studies In Natural Products Chemistry. 2002;(26):293-312.

6. Bathaie S, Mousavi S.New Applications And Mechanisms of Action of Saffron And Its Important Ingredients. Critical Reviews In Food Science And Nutrition.2010; 50(8), 761-786.

7. Samarghandian S, Borji A, Farahmand SK, Afshari R, Davoodi S. Crocus Sativus L. (Saffron) Stigma Aqueous Extract Induces Apoptosis In Alveolar Human Lung Cancer Cells Through Caspase-Dependent Pathways Activation. Biomed Res Int. 2013;2013:1-12.

8. Morjani H, Tarantilis P, Polissiou M, Manfait M. Growth Inhibition And Induction Of Crythroid Differentiation Activity By Crocin, Dimethylcrocetine And Carotene On K562 Tumor Cells. Anticancer Res. 1990;10:1398-406. 
9. Nair SC, Salomi MJ, Varghese CD, Panikkar B, Panikkar KR. Effect Of Saffron On Thymocyte Proliferation, Intracellular Glutathione Levels And Its Antitumor Activity.Biofactors. 1992; 4(1):51-4.

10. Mousavi SH, Tavakkol-Afshari J, Brook A, Jafari-Anarkooli I. Role of Caspases And Bax Protein In Saffron-Induced Apoptosis In MCF-7 Cells. Food Chem Toxicol. 2009; 47(8):1909-13.

11. Akhondzadeh S, Fallah-Pour $\mathrm{H}$, Afkham $\mathrm{K}$, Jamshidi A, Khalighi-Cigaroudi $\mathrm{F}$. Comparison of Crocus Sativus L. And Imipramine In The Treatment of Mild To Moderate Depression: A Pilot Double-Blind Randomized Trial. BMC Complementary And Alternative Medicine. 2004; 4(1).

12. Hosseinzadeh H, Karimi G, \& Niapoor M. Antidepressant Effect of Crocus Sativus L. Stigma Extracts And Their Constituents, Crocin And Safranal, In Mice. Acta Horticulturae. 2004; 650:435-445.

13. Hausenblas HA, Saha D, Dubyak PJ, Anton SD. Saffron (Crocus Sativus L.) and Major Depressive Disorder: A Meta-Analysis Of Randomized Clinical Trials. J Integr Med. 2013; 11(6): 377-383.

14. Nasiri Z, Sameni HR, Vakili A, Jarrahi M, Khorasani MZ. Dietary Saffron Reduced The Blood Pressure And Prevented Remodeling of The Aorta In L-NAME-Induced Hypertensive Rats. Iran J Basic Med Sci. 2015;18(11):1143-1146.

15. Ebrahimi F, Aryaeian N, Pahlavani N, Abbasi D, Hosseini AF, Fallah S, et al. The Effect Of Saffron (Crocus Sativus L.) Supplementation On Blood Pressure, And Renal And Liver Function In Patients With Type 2 Diabetes Mellitus: A DoubleBlinded, Randomized Clinical trial. Avicenna Journal of Phytomedicine. 2019; 9(4):322-333.

16. Imenshahidi M, Razavi BM, Faal A, Gholampoor A, Mousavi SM, Hosseinzadeh H. Effects Of Chronic Crocin Treatment On Desoxycorticosterone Acetate (Doca)-Salt Hypertensive Rats. Iran J Basic Med Sci. 2014;17:9-13.

17. Pitsikas N, Boultadakis A, Georgiadou G, Tarantilis PA, Sakellaridis N. Effects Of The Active Constituents Of Crocus Sativus L., Crocins, In An Animal Model Of Anxiety. Phytomedicine. 2008; 15(12) : 1135 -9.

18. Jafarnia N, Ghorbani Z, Nokhostin M, Manayi A, Nourimajd S, Jahromi, S. Effect Of Saffron (Crocus Sativus L.) As An Add-On Therapy To Sertraline In Mild To Moderate Generalized Anxiety Disorder: A Double Blind Randomized Controlled Trial. Arch Neurosci. 2017; 4(4):e14332.

19. Pitsikas N. Constituents of Saffron (Crocus sativus L.) As Potential Candidates For The Treatment Of Anxiety Disorders And Schizophrenia. Molecules. 2016; 21(3) : 303. 
20.Zarrindast MR, Khakpai F. The Modulatory Role of Dopamine in Anxiety-like Behavior. Arch Iran Med. 2015; 18(9).

21. Halbreich U, Borenstein J, Pearlstein T, Kahn L. The Prevalence, Impairment, Impact, And Burden Of Premenstrual Disphoryc Disorder (PMS/PMDD). Psychoneuroendocrinology. 2003; 28(Suppl.3): 1-23.

22. Agha-Hosseini M, Kashani L, Aleyaseen A, Ghoreishi A, Rahmanpour H, Zarrinara $A$, et al.Crocus sativus L. (Saffron) In The Treatment Of Premenstrual Syndrome: A Double-Blind, Randomised And Placebo-Controlled Trial.BJOG-An International Journal of Obstetrics and Gynaecology. 2008; 115(4): 515-519. 